\title{
Nutrient use efficiency and crop productivity of rice as influenced by dates of planting and nutrient management practices
}

\section{SUBHLAXMI PAL AND SANGEETA JOSHI}

Received : 17.03.2016; Revised : 09.04.2016; Accepted : 05.05.2016

\section{MEMBERS OF RESEARCH FORUM:}

Corresponding author :

SUBHLAXMI PAL, Department of Soil Science and Agricultural Chemistry,

College of Agriculture, Indira Gandhi

Krishi Vishwavidyalaya, RAIPUR (C.G.) INDIA

Co-authors :

SANGEETA JOSHI, Department of Soil

Science and Agricultural Chemistry,

College of Agriculture, Indira Gandhi

Krishi Vishwavidyalaya, RAIPUR (C.G.)

INDIA

\section{Summary}

The nutrient uptake studies were also influenced nutrient management practices and nutrients availability. The major and micronutrient content in grain and straw was also influenced significantly due to application of organics and fertilizers. The higher nutrient contents and their uptake was recorded $\mathrm{T}_{5}(100 \% \mathrm{NPK}+\mathrm{Zn}+\mathrm{S}+\mathrm{GM} @ 6 \mathrm{t} / \mathrm{ha}+\mathrm{FYM} @ 3 \mathrm{t} / \mathrm{ha}+\mathrm{straw} @ 3 \mathrm{t} / \mathrm{ha}$ as mulch $+1 \% \mathrm{Fe}+0.2 \% \mathrm{~B}$ spray $)$ and $\mathrm{T}_{4}(150 \% \mathrm{NPK}+\mathrm{Zn}+\mathrm{S}+1 \% \mathrm{Fe}+0.2 \% \mathrm{~B}$ spray $)$ treatments.

Key words : Nutrient content, Nutrient uptake, Different dates of planting, Rice

How to cite this article : Pal, Subhlaxmi and Joshi, Sangeeta (2016). Nutrient use efficiency and crop productivity of rice as influenced by dates of planting and nutrient management practices. Asian J. Soil Sci., 11 (1) : 146-150 : DOI : 10.15740/HAS/AJSS/11.1/146-150. 